Article

\title{
Tracing the Trends in Sustainability and Social Media Research Using Topic Modeling
}

\author{
Jee Hoon Lee ${ }^{1}$, Jacob Wood $^{2}$ and Jungsuk Kim ${ }^{3, * \mathbb{C}}$ \\ 1 Department of Business Administration, Sejong University, Seoul 05006, Korea; petra@sejong.ac.kr \\ 2 JCU Singapore Business School, James Cook University Singapore, Singapore 387380, Singapore; \\ jacob.wood@jcu.edu.au \\ 3 Department of Economics, Sejong University, Seoul 05006, Korea \\ * Correspondence: js_kim@sejong.ac.kr; Tel.: +82-10-4787-8983
}

\section{check for} updates

Citation: Lee, J.H.; Wood, J.; Kim, J. Tracing the Trends in Sustainability and Social Media Research Using Topic Modeling. Sustainability 2021, 13, 1269. https://doi.org/10.3390/ su13031269

Received: 28 December 2020

Accepted: 22 January 2021

Published: 26 January 2021

Publisher's Note: MDPI stays neutral with regard to jurisdictional claims in published maps and institutional affiliations.

Copyright: (c) 2021 by the authors. Licensee MDPI, Basel, Switzerland. This article is an open access article distributed under the terms and conditions of the Creative Commons Attribution (CC BY) license (https:// creativecommons.org/licenses/by/ $4.0 /)$.

\begin{abstract}
New ideas are often born from connecting the dots. What new ideas have emerged among the two highly trending research topics of sustainability and social media? In this study, we present an empirical analysis of 762 published works that included the terms "sustainability" and "social media" in their abstracts. The bibliographic data, including abstracts, were collected from the Scopus database. In order to conduct the analysis, we used the Latent Dirichlet Allocation (LDA), an unsupervised machine learning algorithm to extract the latent topics from the large quantity of research abstracts without any manual adjustment. The 10 main topics identified from our analysis revealed topographical maps of research in the field. By measuring the variation of topic distributions over time, we identified hot topics (research trends that are becoming increasingly popular over time) and cold topics. Sustainable consumer behavior, Sustainable community and Sustainable tourism were identified as being hot topics, while Education for sustainability was identified as the only cold topic. By identifying current trends in social media and sustainability research, our findings lay a platform from which further studies may abound.
\end{abstract}

Keywords: topic modeling; LDA; research trend; sustainability; social media

\section{Introduction}

Sustainability and social media are two megatrends that have formed a new management paradigm in the 21st century. Both have enhanced customer engagement and have altered the way corporations perceive performance. Unfortunately, many businesses still have not quite found out how the two areas can be successfully brought together. The research that has taken place at the interface between the two fields can be a good reference point. This paper explores this possibility.

Social media plays a vital role in implementing more sustainable operational practices across an organization in that it raises greater awareness of sustainability, enables stakeholders to participate more effectively, and has become an important source of information for business. Competitive advantages rely on the ability of an organization to develop, reconfigure, and incorporate expertise in order to best respond to the changing market climate [1]. Recently, the changing market environment has been as strong as a typhoon, and it is no exaggeration to say that sustainability and social media are in the eye of the typhoon. Based on the resource-based view of the firm, social media is regarded as resources that may enhance organizational capabilities and business performance [2]. Social media consists of seven functional resources: identity, interactions, sharing, presence, partnerships, credibility, and communities [3].

New ideas are often born from connecting the dots. What new ideas have emerged from the two highly trending research topics of sustainability and social media? In this paper, we present an empirical analysis of papers published that included both "sustainability" and "social media" in their abstracts. A huge number of studies have been conducted 
in the fields of sustainability and social media, however, only a small percentage of the research examines the intersection of the two fields. Our bibliographic study provides a meaningful contribution by focusing on the intersection of these two megatrends.

When knowledge reaches maturity, scholars become interested in the existing literature itself because it becomes an important source of information from which further studies may abound [4]. In particular, the study of sustainability requires interdisciplinary research, in that the concept of sustainability incorporates many, if not all, of the activities that people undertake: science and engineering, the environment and ecology, economics and business, sociology and philosophy, and many others [5]. It was indeed shown that sustainability research is much more interdisciplinary than research in general, in that sustainability-based studies more successfully integrate knowledge from the environmental, social, and economic sciences than scientific research [6]. Given the interdisciplinarity of sustainability research the task of grasping the topographic map and the research trends has particularly important implications.

Many attempts have been made to study the sustainability literature in detail and explain what has been learned historically and provide guidance for future studies [7]. Some reviews have delved into the concept of sustainability to derive a more accurate definition of it [8,9]. The most common definition of sustainability is "development which meets the needs of the present without compromising the ability of future generations to meet their own needs," as stated in the Brundtland Report [10]; however, there are different interpretations, with subsequent reviews trying to partially solve the complexity and ambiguity of the concept and to achieve a shared vision among the different stakeholders.

With the advancement of the concept of sustainability, emphasis has turned to the more specific goals of sustainability: economic progress, social development, and the conservation of the environment for future generations. They are called the three pillars of sustainability, and, based on this conceptual foundation, sustainability research has begun to bloom in earnest in each related academic field. In line with this, an assessment of the literature has been actively conducted in accordance with the various academic fields related to sustainability.

For example, the evolution of themes and clusters in circular economy research was analyzed together with an assessment of their interrelation with sustainability [11]. Murphy analyzed existing literature to identify the components of the social pillar, the second axis of sustainability [12]. Albino identified the main dimensions and elements that characterize a "smart city," which is closely related to sustainability on the grounds of the existing literature [13].

In business administration, many reviews exist in the areas of sustainable supply chain or green supply chain where sustainability and supply chain management are integrated [14-16]. There are reviews of the research that has taken place at the interface between sustainability and business strategy, product innovation, and corporate finance, respectively [17-19]. However, existing sustainability literature studies, especially qualitative studies, have several methodological problems that are common in studies adopting similar methodologies [20]. First, there is a problem of selection bias resulting from the subjective classification of research topics. Second, predetermined research categories may not cover all of the research topics, especially when researchers do not know or form a consensus on the research covered in new fields of enquiry. Third, it is not appropriate to name a study as being truly representative of one topic because a piece of research often contains multiple topics.

The topic modeling approach used in this work is one of the promising solutions to these problems. It is an algorithm that mechanically discovers potential topics in a large collection of unstructured documents. Since there is no need to label documents in advance, analysis can be done relatively independently of a human's prior judgments. By defining its latent topics using topic modeling, this thesis aims to delineate the thematic landscape of sustainability and social media study. The Latent Dirichlet Allocation (LDA) model, 
currently the most common topic modeling algorithm, is used to uncover latent topics from 627 "sustainability + social media" papers.

\section{Methods}

\subsection{Research Method}

Topic modeling is a machine learning-based text mining technique that automatically analyzes text data to identify hidden semantic structures within documents. It has been used in a wide range of studies $[20,21]$. Topic modeling identifies a document as a probabilistic distribution over topics, and each topic as a probabilistic distribution over words. Topic modeling is called "unsupervised" machine learning because it does not require tags or training data that have been pre-classified by humans. The observed variable, the word, deduces invisible variables, such as the subjects of the literature, and consequently finds out the topics in the entire literature set and the probabilities that each word will be included in each topic. It has been widely used as a technique for analyzing recent academic trends as it is useful for finding hidden topics in the literature.

Among several algorithms of topic modeling, the Latent Dirichlet Allocation (LDA) is widely used as a representative probabilistic topic model. The model was devised by Blei et al. [22] incorporating the distribution of Dirichlet statistics into the topic modeling process of automatically finding topics. Figure 1 represents the LDA document generation process in which nodes represent random variables.

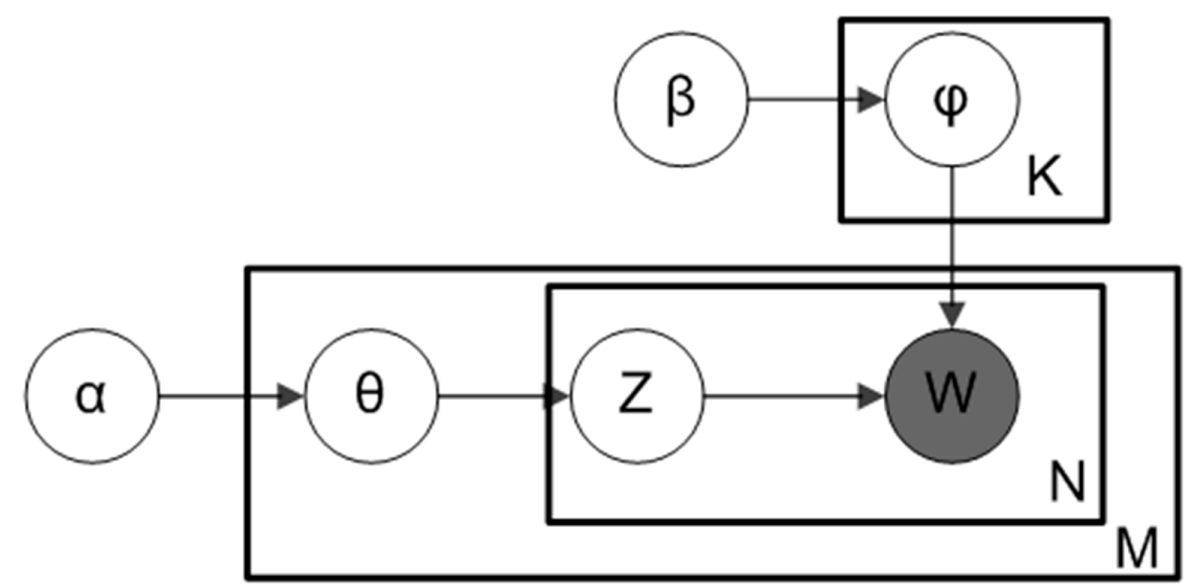

Figure 1. Document generation process of Latent Dirichlet Allocation (LDA).

The shaded node $\mathrm{W}$ means a word that we can observe, and the box-shaped enclosures mean that the process is repeated. $M$ represents the total number of papers, and $K$ is the number of topics across a corpus, while $\mathrm{N}$ is the total number of words in all documents. $\theta$ denotes the topic distribution of each literature, and $\varphi$ represents the word distribution of each topic. $\alpha$ and $\beta$ are hyperparameters, values that are set directly by the user in the model. LDA assumes that $\theta$ and $\varphi$ are Dirichlet distributions that follow hyperparameter $\alpha$ and $\beta . z$, on the other hand, represents the topic to which each word belongs.

The values we want to obtain from LDA are $z, \theta$, and $\varphi$. As LDA observes the actual words in the literature, i.e., $W$, it gives each word a random topic in turn (i.e., a random $z$-value is determined). It then updates the Dirichlet distribution of $\theta$ and $\varphi$ according to this result. This process is repeated to find the most likely z-values for all possible cases, and to estimate $\theta$ and $\varphi$. It is an iterative simulation process.

When conducting LDA, the user must select $\alpha$ and $\beta$, and the number of subjects $K$ beforehand. The result of the analysis depends on these choices. A smaller $\alpha$ results in a distribution in which a document mostly consists of a few topics, while a larger $\alpha$ results in a document consisting of several topics of similar weight. In addition, the larger the value of $\beta$, the higher the similarity between the topics, while the smaller the value of $\beta$, the more distinct the topics are [21,23]. 


\subsection{Data}

The sample of publications for this paper was obtained from the Scopus database. We used two different search strings. The first used "sustainab" responsibility)," while the second only used "social media." By choosing "sustainab" instead of "sustainability" as the search term, we could include similar concepts such as "sustainable development" or derivative concepts such as "sustainable supply chain." We included CSR as the search term because sustainability and CSR are often used interchangeably and both are "umbrella constructs," i.e., a broad concept used loosely to encompass a broad set of diverse phenomena $[24,25]$.

We limited the subject area of our search to management, economy, and social sciences, and the document type to article and review. Finally, a total of 762 articles were produced as the data set (corpus) for this study. It included the basic bibliometric information about the articles such as titles, authors, journals, and publication year, abstracts, and keywords. We did not limit the date of publication. One thing we were aware of when applying the LDA was that a sufficiently large size of text corpus is needed to ensure accurate and meaningful results, since the statistics behind topic modeling algorithms require a certain volume of text [26]. The size of the corpus depends on both the number of documents and the length of each document. The existing literature to date lacks theoretically justified guidelines regarding minimal corpus size, however, experimental studies suggested that the results of LDA for corpora with few documents (i.e., <100) are very difficult to interpret, even if the documents are long [26]. The number of documents in our study was 762, well over 100.

Furthermore, a meta-analysis of 416 topic modeling studies showed that documents have an average length of 84 words (median $=14$ words) [26], which is below the general length of research abstracts (100-500 in general). The reason why the average length is short is that researchers typically use topic modeling to analyze large amounts of short texts such as social media posts. In sum, the data set of this study consisted of 762 abstracts and was considered an appropriate size for extracting 10 topics.

Figure 2 depicts the annual changes in the number of articles. It was shown that the number of "sustainability + social media" articles has grown rapidly from only one article in 2007 to 231 in 2020. Four papers scheduled to be published in 2021 were also included in the data set, but were not shown in the figure.

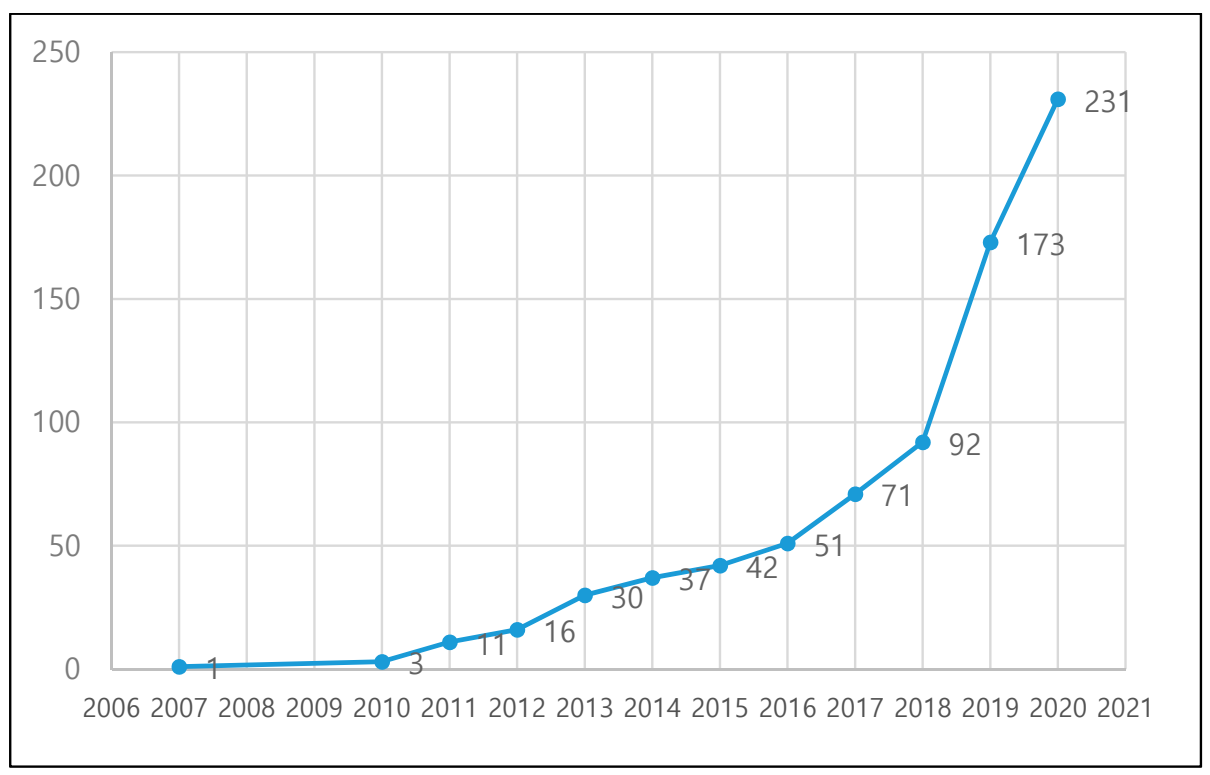

Figure 2. Number of "sustainability + social media" articles.

Sustainability has emerged as one of the dominant terms in the social sciences since the Brundtland Report of 1987 [27]. Figure 3 shows the time evolution of the research 
including the use of the words "sustainability" and "social media," respectively, in their abstracts. From this, an exponential increase in the number of sustainability-themed papers since the 2000s can be seen. On the other hand, social media-themed papers were very rare before the 2010s, and have exploded since the 2010s. This is natural, considering that Facebook and Twitter, the leading social media sites, were established in 2004 and 2006, respectively.

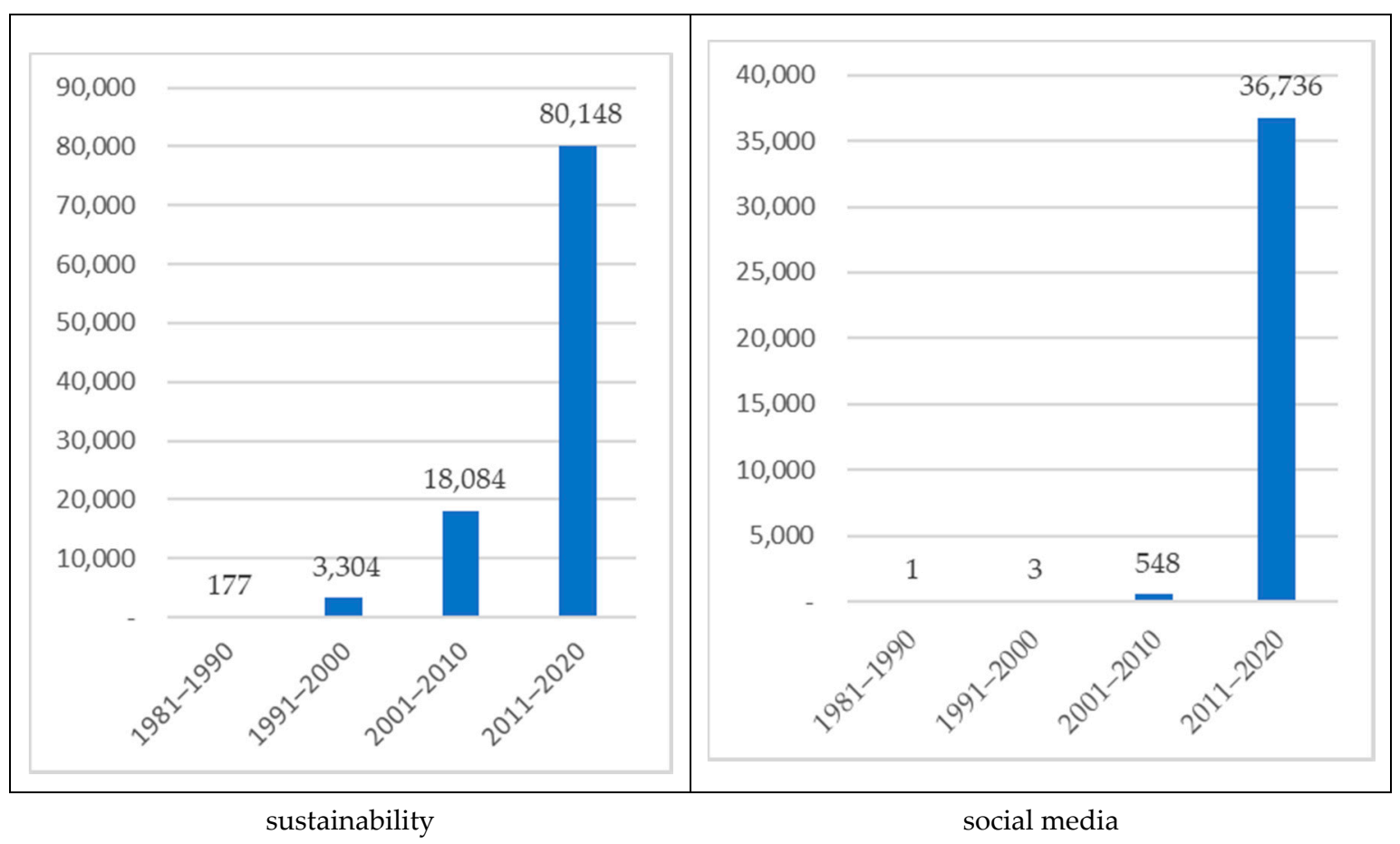

Figure 3. Number of articles having "sustainability" and "social media," respectively.

One thing we needed to be careful about was that there were a number of studies that used the terms "sustainable" or "sustainability" in the dictionary sense of "continuous" or "long lasting." These papers often made no special mention of sustainable development and did not take into account universal sustainability issues. This is often the case when using compound words like sustainable marketing, or sustainable supply chain management [28]. The problem is that if any continuous or long lasting system is called sustainable, it creates controversy over what should be sustained [29]. For example, there is a question of whether to continue practices that are harmful to the environment.

Nevertheless, many of the studies that discussed the sustainability of existing systems or practices were more or less related to the economic pillar of sustainability. In that case, we could say they were related to sustainability in a broad sense. In addition, subjective judgments about which criteria to define sustainability will inevitably be involved if we limited our search to sustainability in a narrow sense.

Table 1 shows the top 10 sources of the articles extracted. The proportion of Sustainability (MDPI, Switzerland) was overwhelmingly high, followed by the Journal of Cleaner Production, the Journal of Business Ethics, and the Journal of Sustainable Tourism by a substantial margin. 
Table 1. The number of "sustainability + social media" articles for top 10 sources.

\begin{tabular}{ccc}
\hline Rank & Source & The Number of Articles \\
\hline 1 & Sustainability (MDPI, Switzerland) & 152 \\
2 & Journal of Cleaner Production & 21 \\
3 & Journal of Business Ethics & 16 \\
4 & Journal of Sustainable Tourism & 14 \\
5 & Developments in Corporate Governance & 12 \\
5 & and Responsibility & 12 \\
7 & Public Relations Review & 9 \\
7 & Corporate Communications & 9 \\
9 & Corporate Social Responsibility and & 8 \\
10 & Environmental Management & 7 \\
\hline
\end{tabular}

The results highlighted the obvious point that certain journals specializing in sustainability research had a very high proportion of articles in our data set, given the purpose they serve. Sustainability, which had the highest percentage, states on its website that it "provides an advanced forum for studies related to sustainability and sustainable development." Moreover, the Journal of Cleaner Production says that it focuses on "cleaner production, environmental, and sustainability research and practice."

\subsection{Preprocessing}

All words contained in the titles, abstracts, and keywords of the articles of the dataset were subject to topic modeling analysis. The abstract was a compressed representation of a study and could be used as a substitute for the paper because it typically contained enough key words on the subject of the study [23].

Before the LDA analysis, the texts of the corpus were passed through a series of preprocessing steps. We extracted only nouns from the corpus. When the capital and lowercase letters were displayed differently or words with a hyphen or midpoint were recognized as different words, we standardized them to ensure consistency to the extent that they did not affect the analysis. We removed several user-defined stop-words that frequently appear in the abstracts of academic articles, such as "analysis," "paper," "research," and "issue." We regarded "social media" as a word. We performed this preprocessing using the Biblio Data Collector, an extension of NetMiner, a social network analysis (SNA) program that is used for the LDA inference as well.

After the preprocessing, the final number of words extracted from the analysis was 7505. One of the most important variables to be determined for the LDA inference was the number of topics. We closely investigated the topic-word distributions for different numbers of topics, such as $10,15,20$, before we finally decided to use 10 topics.

Regarding the number of topics, no commonly accepted rules for analytically determining this number for a given corpus have emerged so far, apart from performing a search over different topic numbers and comparing the coherence and exclusivity of the resulting model. However, the meta-analysis of 416 topic modeling studies showed that half of the studies contained between 10 and 50 topics, with the average study having 35 topics [26]. $\alpha$ and $\beta$ should also be determined by the researcher. We set $\alpha$ at 0.1 and $\beta$ at 0.01 , and the number of simulations at 1000 .

\section{Results and Discussion}

\subsection{Identifying Topics}

Two types of posterior probability distributions were obtained by running LDA: the topic distribution of each paper and the word distribution of each topic. For example, for the study "Using social media for CSR communication and engaging stakeholders," the LDA estimated the probability distribution (see Table 2). 
Table 2. An example of ex-post study-topic distribution.

\begin{tabular}{cccccccccc}
\hline 1st & 2nd & 3rd & 4th & 5th & 6th & 7th & 8th & 9th & 10th \\
Topic & Topic & Topic & Topic & Topic & Topic & Topic & Topic & Topic & Topic \\
\hline 0.019 & 0.002 & 0.004 & 0.111 & 0.024 & 0.003 & 0.007 & 0.103 & 0.002 & 0.724 \\
\hline
\end{tabular}

As the example shows, this study had the largest number of words related to topic 10 , which amounted to $72.4 \%$, followed by topic 5 with $11.1 \%$. Topics 2 and 9 were the least relevant, with only $0.2 \%$. The sum of 10 probabilities was 1 . LDA estimated this probability distribution as many as the number of papers (i.e., 762).

An examination of the word distribution for each topic was now provided. For example, for topic 10, the LDA analysis estimated the probability distributions (see Table 3).

Table 3. An example of ex-post topic-word distribution.

\begin{tabular}{|c|c|c|c|c|c|c|c|c|}
\hline $\begin{array}{c}\text { 1st } \\
\text { Keyword }\end{array}$ & $\begin{array}{c}\text { 1st } \\
\text { Prob. }\end{array}$ & $\begin{array}{c}\text { 2nd } \\
\text { Keyword }\end{array}$ & $\begin{array}{l}\text { 2nd } \\
\text { Prob. }\end{array}$ & $\begin{array}{c}\text { 3rd } \\
\text { Keyword }\end{array}$ & $\begin{array}{c}\text { 3rd } \\
\text { Prob. }\end{array}$ & $\cdots$ & $\begin{array}{l}\text { 7505th } \\
\text { Keyword }\end{array}$ & $\begin{array}{l}\text { 7505th } \\
\text { Prob. }\end{array}$ \\
\hline CSR & 0.119 & communication & 0.053 & $\begin{array}{l}\text { social } \\
\text { media }\end{array}$ & 0.048 & $\ldots$ & $3 \mathrm{D}$ & 0.000 \\
\hline
\end{tabular}

In other words, the probability of including the word "strategy" in topic 10 was the highest at $11.9 \%$, followed by "communication" at $5.3 \%$. The probability of containing the word "3D" was the lowest with zero. The LDA calculated the probabilities of all 7505 words for each topic. The sum of 7505 probabilities was 1 . The LDA estimated this distribution of probabilities as many as the number of topics (i.e., 10).

Based on these two kinds of probability distributions, the LDA derived 10 topics. Table 4 represents the list of these 10 topics, with the top 10 words shown for each topic, and the proportion of the topic in the entire corpus. Topics were rearranged and renumbered in descending order of their proportion. The LDA classifies topics by algorithm but does not name them, and the topics should be labeled by the researchers. The authors of this work labeled the topic names through discussion, analyzing the contents of the top words for each topic and the most relevant studies with high loadings for each topic.

Table 4. Identified topics from the LDA.

\begin{tabular}{|c|c|c|}
\hline Topic & Top 10 Relevant Words & Share \\
\hline (T1) Education for sustainability & $\begin{array}{l}\text { sustainability, social media, community, development, education, } \\
\text { practice, student, information, communication, medium }\end{array}$ & 0.1568 \\
\hline (T2) Sustainable communication & $\begin{array}{l}\text { CSR, communication, social media, firm, stakeholder, message, } \\
\text { engagement, strategy, Facebook, Twitter }\end{array}$ & 0.1461 \\
\hline (T3) Sustainable consumer behavior & $\begin{array}{l}\text { consumer, social media, brand, behavior, intention, effect, influence, } \\
\text { attitude, factor, theory }\end{array}$ & 0.1263 \\
\hline (T4) Sustainable marketing & $\begin{array}{l}\text { marketing, business, social media, firm, sustainability, management, } \\
\text { performance, strategy, product, medium }\end{array}$ & 0.1141 \\
\hline (T5) IT and finance for sustainability & $\begin{array}{l}\text { network, information, medium, technology, sustainability, user, news, } \\
\text { system, content, internet }\end{array}$ & 0.1093 \\
\hline (T6) Sustainable development & $\begin{array}{l}\text { change, economy, person, country, health, development, world, } \\
\text { policy, impact, year }\end{array}$ & 0.0730 \\
\hline (T7) Sustainable community & $\begin{array}{l}\text { system, social media, management, service, traffic, planning, } \\
\text { sentiment, data, quality, review }\end{array}$ & 0.0721 \\
\hline (T8) Sustainable activism & $\begin{array}{l}\text { food, social media, government, citizen, movement, health, } \\
\text { governance, medium, activism, citizenship }\end{array}$ & 0.0711 \\
\hline (T9) Sustainable tourism & $\begin{array}{l}\text { tourism, tourist, city, destination, development, place, social media, } \\
\text { sustainability, travel, visitor }\end{array}$ & 0.0700 \\
\hline (T10) Sustainable supply chains & $\begin{array}{l}\text { customer, value, chain, industry, social media, supply, relationship, } \\
\text { activity, language, service }\end{array}$ & 0.0612 \\
\hline
\end{tabular}




\subsection{Review of Topics}

The 10 topics extracted represented an aerial view of the research in the field. Topics were grouped into three pillars of sustainability encompassing economic, social, and environmental factors or "goals." Though the three pillars were closely interwoven with each other and not mutually exclusive, we categorized T6 (Sustainable development) and T7 (Sustainable community) as having the greatest connection with the environmental pillar, and T1 (Education for sustainability) and T8 (Sustainable activism) with the social pillar. The rest of the topics were classified as the economic pillar. Among them, T2 (Sustainable communication), T3 (Sustainable consumer behavior), T4 (Sustainable marketing), T10 (Sustainable supply chains) included the expansions of existing business and management fields, with the first three of them also including marketing. The topic classification of the "sustainability + social media" studies showed a topographic map distinguished from the general "sustainability" studies in social science or management. The 10 topics did not cover all areas of sustainability, as not all fields actively studied the relationship of sustainability and social media.

We compared our findings to that of Pizzi et al. [30], who analyzed the research trends of sustainability in business administration using search term "SDGs (sustainable development goals)" and the SNA methodology. They identified four research themes: technological innovation, firms' contributions in developing countries, non-financial reporting, and education for SDGs. All four of them correspond well to the 10 topics we outlined (T5, T6, T5, T1, in particular). A brief overview of each topic is provided below, especially focusing on the interaction of sustainability and social media.

(T1) Education for sustainability

Education is critical to ensuring sustainable development, in that it fosters environmental sustainability awareness. Education for Sustainability (EfS) or Education for sustainable development (ESD) is an approach aimed at building skills that enable people to focus on their own behaviors, taking into account their present and future social, cultural, economic, and environmental impacts [31,32]. The first international paper to recognize education as an important instrument for achieving sustainable development was Agenda 21, which outlined areas of action for education [33]. UNESCO stressed that education for sustainable development requires participatory teaching and learning methods that motivate and empower learners to change their behaviors and take action for sustainable development [34]. With the rise of social media, the education field has been paying closer attention to how the tool can be best utilized. Social media can certainly be used to share information and raise awareness about the importance of sustainability among students and continuously engage them in environmental causes [35]. Social media can be a particularly important tool to teach a generation called "digital natives." [36]. A lot of case studies have been conducted in this field, including an assessment of Facebook as an edutainment medium to engage students in sustainability and tourism [37]. Wang, S. and Wang, H. conducted a qualitative analysis of 12 cases of social media-based knowledge sharing [38]. They observed that two main success drivers were the personalization of corporate entities and the socialization of engagement on social media.

(T2) Sustainable communication

Corporations should not only behave in a socially conscious manner, they need to also strategically communicate their sustainability practices to recognize and meet the needs of their public [39]. However, even businesses that are dedicated to CSR activities sometimes fail to properly communicate their good deeds [40].

The use of social media to communicate CSR issues is considered an effective way to foster organization-public relationships and achieve public credibility [41,42]. Literature also showed that CSR communication through interactive channels can enhance corporate reputation [43]. Many companies, therefore, have added social media as another outlet for their external and internal communication about sustainability [44]. In particular, social media differs from conventional media in that it enables organizations and stakeholders to have a two-way interactive experience [44]. 
However, the public is sometimes cynical about CSR messages as they are perceived as self-serving rather than truly caring for the community [45]. CSR messages may not be viewed as favorably as other messages, like promotions or corporate updates [46]. The implementation of CSR practices and the expectations of what it will bring need to be managed [47]. The implementation of CSR is a double-edged sword because it can lead to an inflation of CSR claims beyond what is practically implemented [48].

(T3) Sustainable Consumer Behavior

Sustainable consumer behavior is of particular importance to marketers [49]. In order to take advantage of this opportunity, studies have highlighted the important part that social media plays in molding consumer opinions, influencing attitudes and purchasing decisions [50]. This is very evident in the sustainability space, where social media's role in shaping the consumer's green behavior and purchase intention has been significant [51]. Research has shown that social networks help to encourage environmental behavior [52], while celebrity engagement through social media platforms also influences consumer attitudes toward green products [53]. Social media is now a key communication channel for businesses, with the platform widely adapted as an important means of sharing information and ideas, creating content, and expressing opinions [54]. Moreover, social media has revolutionized the way in which companies and their respective customers communicate by providing a more interactive buying experience [55], and a more effective means of obtaining important product information [56].

In studies on the impact of social media on buyer intention, it was found that social media messages help to increase a consumer's willingness to buy, while social media interactions directly impact buying behavior by encouraging consumers to look like their peers [57]. In other consumer behavior studies, social media was found to be useful and trustworthy by consumers [58]. In terms of social media's influence on sustainable forms of consumer behavior, social media influencers provide a very effective means of illustrating the benefits of adopting a greener, more sustainable form of lifestyle [59]. More recently, Pop et al. examined the impact that social media has on consumers' altruistic and egoistic motivation, as well as their attitudes and subjective norms toward green cosmetics products [51]. Using the theory of planned behavior with prediction of purchase intention as the key component, the study found that social media as a source of information has a clear role in consumer motivation formation and consumers' intention to purchase green cosmetics.

(T4) Sustainable Marketing

Many organizations strive to better understand the features and preferences of their customers by utilizing social media services [60]. In recent years, as customer preferences have become more environmentally focused, marketers and businesses have sought to cater to such changes. As such, the issue of sustainability-orientated marketing and, in particular, interest in green marketing, has rapidly increased [61]. Sustainable marketing is a threedimensional construct that includes environmental responsibility, social engagement, and economic growth $[62,63]$. Through these pillars, businesses have been keen to develop operational models that improve financial performance, with much research suggesting that socially and environmentally responsible practices have the potential to generate higher levels of profitability and a more positive consumer perception of a business [62,64-66].

(T5) IT and finance for sustainability

Information and Communications Technology (ICT), including social media, and new financial opportunities such as green bonds and crowdfunding are becoming a powerful means of achieving sustainable innovation. As IT capabilities as a crucial strategic enabler continue to grow across business, more organizations have recognized the need to think more holistically about how IT can help achieve corporate sustainability activities. Companies are now leveraging IT abilities to facilitate sustainability initiatives across the enterprise, including data center optimization, teleworking, and paperless billing [67]. In addition, the shared economy brought about by advances in ICT also helps with the transition to more sustainable activities [68,69]. The negative issues arising from a platform 
economy should be resolved by the precise governance of the entire innovation ecosystem, with an emphasis on social responsibilities [70]. In the framework of sustainable innovation processes, users are described as much more constructive contributors [71,72]. Users' contributions can include the creation of new supply systems, the shaping of specific technology characteristics, the development of new usage patterns, particularly in the early stages of development [73].

Social media and finance are connected in a new way to promote sustainability; a case in point is crowdfunding. It is an appropriate source of funding for sustainable entrepreneurs who not only focus on the profit-seeking goal but also have to balance between economic, social, and ecological goals [74]. From a finance perspective, sustainability refers to the fact that investors and other stakeholders increasingly use non-financial performance measures such as the environment, society, and governance as important decision criteria. Investors, consumers, and suppliers are increasingly aware of a company's CSR or Green ranking, given how it drives their investment and purchasing decisions [75]. Corporations are increasingly inclined to construct a "green image," which translates into real value for businesses [76]. Consumer communication through social media plays a vital role in this process.

(T6) Sustainable development

All 10 topics classified by the LDA naturally address sustainability, however, this topic in particular corresponds to the general discussion of sustainability or sustainable development. This can also be seen from the relatively high share of words like "country," "world," "policy," "economy," and "climate" in the word distribution of the topic. In other words, this topic deals with the status quo, obstacles, and the path toward the sustainable development from a global, national, macro, and policy perspective. The term "sustainable development" is often used interchangeably with sustainability itself and encompasses other sustainability topics [77]. However, considering the general nature of the topic, we labeled the topic as such.

This topic also includes how social media can help achieve sustainability transformation. Daigle and Vasseur emphasized the need for transformational change as the Earth is reaching the limit of its resources, and they suggested that the solution can come from education and social media [78]. Intensifying the government's narratives in social arenas through the use of newspapers and social media platforms can help to make environmental issues more politically and socially relevant $[79,80]$. Ghazali et al. underscored the importance of public awareness in mitigating the negative externalities associated with $\mathrm{CO}_{2}$ emissions, climate change, and carbon capture and storage (CCS) through a survey of residents in five states of Malaysia [81]. The analysis of the EU's social media communication efforts presented the likely view [82], while Gupta showed how the power of social media can be leveraged for social goods such as the provision of micro lending in India [83].

(T7) Sustainable community (city)

A sustainable community refers to communities planned, built, or modified to promote sustainable living. It is continually adjusting to meet the social and economic needs of its residents while preserving the environment's ability to support it [84]. The term is sometimes used synonymously with "sustainable city." There are four drivers of a sustainable community: multiplying social capital, efficient use of urban space, minimizing consumption of natural capital, mobilizing citizens and their governments [84].

It is noteworthy that advances in ICT technologies, including social media, have begun to play a major role in creating sustainable cities. In this regard, a new term, Smart city, has emerged, the concept of which is based on urban development by integrating technologies and systems to efficiently and securely administer the city resources, with the aim of improving citizens' quality of life, community development, and protecting the environment [85].

ICT and social media can be important sources of information for community design and management [86]. For example, spatial information aggregated on social media, such as 
POI (point of interest) information, can be used to identify urban population dynamics and assist in urban planning [87]. Cities can utilize a variety of structured and unstructured data including social media posts to guide the creation of sustainable and safer traffic systems [88]. Social media is also used to assess the quality of the environment. Wang et al. developed an index that measures the quality of the environment by analyzing what people post about the environment on social media, and calculated the index for 27 Chinese provinces [89]. In addition, social media can foster engagement and self-organization in participatory urban planning and neighborhood governance [90].

(T8) Sustainable activism

Individuals can engage in sustainable activism more effectively using ICT, including social media, which is often called digital activism. Activists for sustainability are often confronted with an array of legal restrictions and financial restraints, and the internet represents an attractive new opening for activists. Cyberspace offers room for expression in a relatively uninhibited space with low financial and social costs [91]. Shim showed that social media platforms such as Twitter can quickly and efficiently build an issue-based advocacy group in Korea [92]. However, activists and NGOs need effective communication strategies. $\mathrm{Vu}$ et al. analyzed 289 global climate NGOs' framing of climate change to find that of the three protest frames (diagnostic, prognostic, motivation), diagnostic was the most popular [93]. Persuasive technology (PT) can not only support activists with information and communication technologies on an individual level, but also support communication and cooperation among individuals for collective action [94].

As activists move from alternative media platforms to commercial social media platforms, the users face increasing challenges in protecting their online security and privacy. While social media offers an unprecedented level of visibility for activists, the risk of being monitored by corporations is inevitable [95].

(T9) Sustainable tourism

Since the 1980s, sustainable tourism has been at the forefront of academic enquiry [96]. Sustainable tourism development is defined by the United Nations World Tourism Organization (UNWTO) as a form of tourism development "that takes full account of its current and future economic, social and environmental impacts, addressing the needs of visitors, the industry, the environment and host communities" [97]. The tourism development literature is vast, with a wide range of topics covered, such as tourism sustainability [98], indigenous tourism [99], cultural tourism [100], demand-based tourism development [101], tourism and regional economic development $[102,103]$, and the impact of tourism development on the environment [104]. An emerging theme within the field has been the role that social media plays in driving sustainable tourism. Like other areas across the business landscape, social media has become an important facet of the tourism sector, with tourists sharing their experiences online [105]. Social media's user-generated content [106] represents a very cost effective and efficient means of reaching existing and new customer bases [107]. In addition to this, the platform was also found to be a key driver in travel purchase decisions [107].

Furthermore, social media portals such as Tripadvisor have become a key gateway for sharing tourism experiences online. In research on the use of social media by tourists, studies such as that by Ayeh et al. [106] have focused on the role of social media in purchase decision-making as well as travel planning, while other works have covered trust and reliability issues in social media [108]. These studies have shown that despite the market reach and revenue benefits of social media, the platform has come under intense scrutiny in recent years [109], in particular, over the trust issues that have emerged with businesses using social media to post potentially false reviews to enhance their own reputation or destroy that of their competition [110].

(T10) Sustainable supply chains

One of the biggest challenges for businesses nowadays is the growing need for incorporating environmentally, socially, as well as economically sustainable choices into supply chain and logistics practices [111]. A growing number of businesses now identify their 
supply chain partners as co-responsible for sustainable management [112,113]. Companies have also begun to pay attention to the role of social media in sustainable supply chain management. Social media can affect decision-making, and affiliated partners in the supply chain may benefit from strong social media coordination and cooperation [114]. In particular, with social media empowering customers and social communities to actively participate and collaborate in sustainable practices by becoming co-designers, co-producers, and co-marketers, the role of the customers in achieving sustainability in all supply chain operations has grown [115]. Accordingly, a growing number of companies exploit social media to promote a sustainable lifestyle in various ways, some nurture customer communities, while some educate customers [115].

\subsection{Trends in Topics}

\subsubsection{Topic Proportion over Time}

Based on the LDA analysis results, we distinguished between topics that were actively studied over time (hot topics) and topics that were increasingly not studied (cold topics). This was one of the most attractive applications of this analysis [23]. We made this distinction by observing the changes in the proportion of each topic over time.

A linear regression model was built for each topic with time as an independent variable and the topic proportions in the corresponding years as a dependent variable. We estimated Equation (1) where $\theta_{j t}$ is the average share of topic $j$ in year $t$.

$$
\theta_{j t}=\alpha_{j}+\beta_{j} t+\varepsilon_{j}
$$

The key area of interest in this study is the sign of the coefficient $\beta_{j}$. If this value was positive (negative), it was classified as a hot topic (cold topic) (see Table 5). As a result of the analysis, three hot topics and one cold topic were derived at the 5\% significance level. (T3) Sustainable consumer behavior, (T7) Sustainable community, (T9) Sustainable tourism were classified as hot topics, while (T1) Education for sustainability was classified as a cold topic. The years 2007 and 2021 were excluded from the regression because there were only four papers scheduled to be published in 2021 and one in 2007 located in the corpus. Figure 4 shows the proportions of changes of the 10 topics over time.

From the results, we observed that the research trends across the fields of sustainability and social media have become more diverse and specific.

In other words, the research's center of gravity has shifted from general discussion to specific applications. This was well represented by the statistically insignificant change in the proportion of (T6) Sustainable development, which corresponds to the general discussion of sustainability research that deals with global, national, macro, and policy issues, while (T7) Sustainable community and (T9) Sustainable tourism, which correspond to specific applications of sustainability in smaller areas, have emerged as hot topics.

Table 5. Regression results and topic types.

\begin{tabular}{cccc}
\hline Topic & Slope $\left({ }^{*} \mathbf{1 0 0 0}\right)$ & $p$-Value & Type \\
\hline (T1) Education for sustainability & -14.356 & $0.0043^{* * *}$ & Cold \\
(T2) Sustainable communication & 1.156 & 0.8942 & \\
(T3) Sustainable consumer behavior & 12.947 & $0.0021^{* * *}$ & Hot \\
(T4) Sustainable marketing & -9.234 & $0.0538^{*}$ & \\
(T5) IT and finance for sustainability & -0.326 & 0.8974 & \\
(T6) Sustainable development & -1.681 & 0.1316 & \\
(T7) Sustainable community & 2.968 & $0.0311^{* * *}$ & Hot \\
(T8) Sustainable activism & 1.321 & 0.4138 & \\
(T9) Sustainable tourism & 5.626 & $0.0126^{* * *}$ & Hot \\
(T10) Sustainable supply chains & 1.58 & 0.2776 & \\
\hline$* 0.1^{* * *}$ P<0.01. Slope is multiplied by 1000 & & &
\end{tabular}

${ }^{*} p<0.1,{ }^{* * *} p<0.01$. Slope is multiplied by 1000 . 


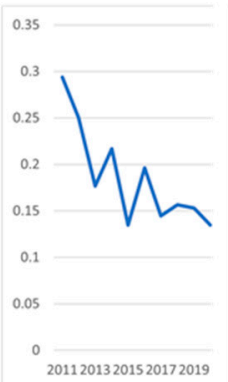

(T1) Education for sustainability

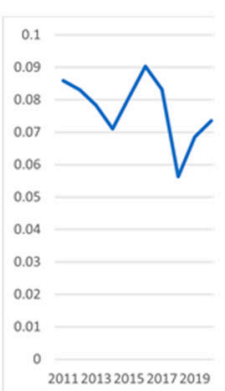

(T6) Sustainable development

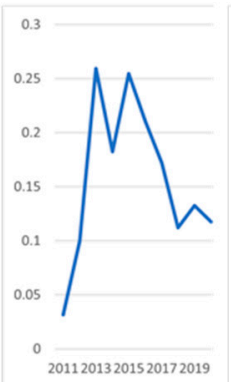

(T2) Sustainable

communication

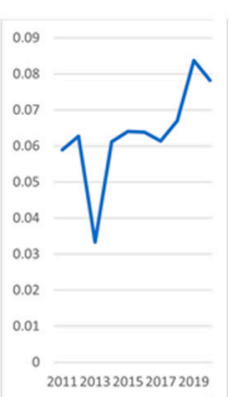

(T7) Sustainable

community

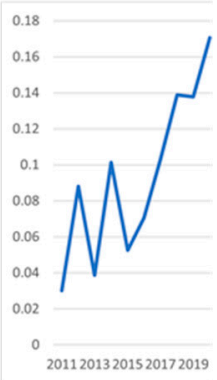

(T3) Sustainable

behavior

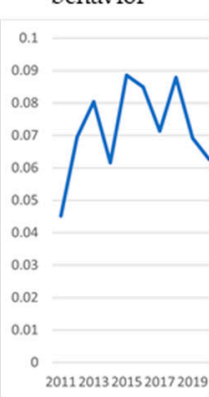

(T8) Sustainable

activism

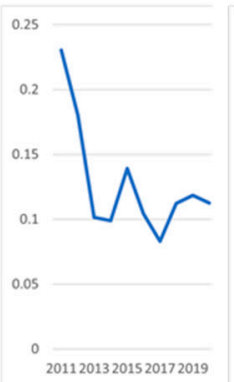

(T4) Sustainable marketing

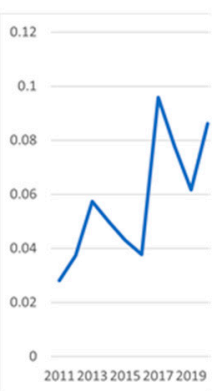

(T9) Sustainable tourism

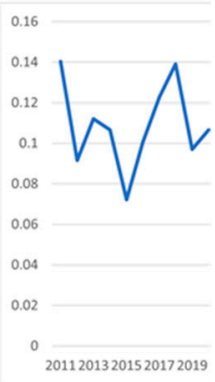

(T5) IT and

finance for

sustainability

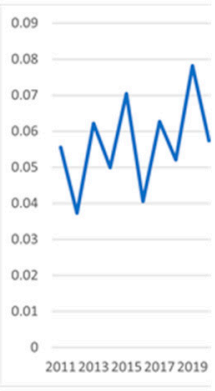

(T10) Sustainable

supply chain

Figure 4. Proportion changes of topics over time.

This trend also appeared in marketing. Among the three topics closely related to marketing (T2, T3, T4), the proportion of (T4) Sustainable marketing, which corresponds to the general discussion did not change significantly over time. On the other hand, (T3) Sustainable consumer behavior, has emerged as a hot topic, which could be interpreted as reflecting companies' growing emphasis on implementing effective sustainability strategies on the basis of an accurate understanding of consumer behavior and social media.

This movement from big to small and from macro to micro can be partly explained by the shift of leadership in sustainable development from nations to corporations. Since the year 2000, most countries have shifted attention from sustainable development to other pressing issues, such as the War on Terror and the financial crisis [116]. Meanwhile, corporations have become exposed to immediate consumer feedback-for example, consumer boycotts of the company brand-enabled by the growing impact of social media and, as such, have less freedom to risk failure by ignoring social media [116].

One thing we should keep in mind is that the topics dealt with in this paper are "sustainability + social media," not "sustainability" in general. Therefore, we should interpret the rise of (T7) Sustainable community, for example, as an increase in the "sustainable community + social media" research.

Another noticeable finding was that (T1) Education for sustainability was the only cold topic. The topic accounted for more than $25 \%$ of the entire corpus between 2010 and 2012 , but decreased to $13.5 \%$ by 2020 . This decline reflects the fact that the proportion of "education for sustainability" papers that also deal with the "social media" issue, has fallen, rather than there being a decline of general "education for sustainability" research itself.

Additional searches were also conducted that showed that the number of papers from a search for "sustainability" in Scopus increased 236\%, from 9199 in 2010 to 30,864 in 2020, while the number of papers from a search for "education for sustainability" or "education for sustainable development" increased 208\%, from 131 to 403 . It was unclear whether the second topic was studied in relatively fewer instances.

A topic's rise and fall may reflect the influence of social media. For example, the information obtained from social media, such as spatial information, may be indispensable 
in sustainable community design and operation. On the other hand, the role of social media in sustainability education is not important enough to say that it is indispensable. In addition, social media's negative impact on education, such as in the lack of critical thinking, break-up in study connectivity, and health hazards [117], may outweigh the positive impact.

The reason why (T9) Sustainable tourism has become a hot topic is that sustainable tourism itself has gained significant popularity, and social media is playing a vital role in its success, through sharing experiences and reaching a new customer base, as mentioned earlier.

\subsubsection{Topic Proportion across Journals}

Table 6 provides the proportions of the topics that were located in the top 10 journals. The top two topics for each journal are highlighted in bold. The composition of topic portfolios of the 10 journals clearly demonstrated their unique aims and scope.

Table 6. Topic compositions of top 10 sources.

\begin{tabular}{|c|c|c|c|c|c|c|c|c|c|c|}
\hline & (T1) & (T2) & (T3) & (T4) & (T5) & (T6) & (T7) & (T8) & (T9) & (T10) \\
\hline $\begin{array}{c}\text { Sustainability (MDPI, } \\
\text { Switzerland) }\end{array}$ & $14.9 \%$ & $4.4 \%$ & $19.8 \%$ & $10.8 \%$ & $13.3 \%$ & $7.9 \%$ & $7.0 \%$ & $4.7 \%$ & $11.5 \%$ & $5.6 \%$ \\
\hline Journal of Cleaner Production & $7.6 \%$ & $1.6 \%$ & $10.6 \%$ & $12.0 \%$ & $17.3 \%$ & $7.9 \%$ & $18.8 \%$ & $7.9 \%$ & $1.5 \%$ & $14.8 \%$ \\
\hline Journal of Business Ethics & $6.7 \%$ & $48.6 \%$ & $13.9 \%$ & $3.7 \%$ & $7.6 \%$ & $3.6 \%$ & $1.8 \%$ & $6.7 \%$ & $1.2 \%$ & $6.3 \%$ \\
\hline $\begin{array}{c}\text { Journal of Sustainable } \\
\text { Tourism }\end{array}$ & $6.1 \%$ & $4.7 \%$ & $16.8 \%$ & $7.8 \%$ & $8.3 \%$ & $3.7 \%$ & $11.4 \%$ & $7.2 \%$ & $29.3 \%$ & $4.9 \%$ \\
\hline Developments in Corporate & & & & & & & & & & \\
\hline $\begin{array}{l}\text { Governance and } \\
\text { Responsibility }\end{array}$ & $5.0 \%$ & $58.2 \%$ & $3.2 \%$ & $9.9 \%$ & $2.8 \%$ & $6.3 \%$ & $0.9 \%$ & $10.6 \%$ & $1.0 \%$ & $2.2 \%$ \\
\hline Public Relations Review & $4.9 \%$ & $56.5 \%$ & $12.5 \%$ & $2.6 \%$ & $5.4 \%$ & $4.1 \%$ & $1.7 \%$ & $1.0 \%$ & $1.1 \%$ & $10.1 \%$ \\
\hline $\begin{array}{c}\text { Corporate Communications } \\
\text { Corporate Social }\end{array}$ & $4.7 \%$ & $67.1 \%$ & $9.3 \%$ & $4.5 \%$ & $6.1 \%$ & $0.6 \%$ & $2.1 \%$ & $0.6 \%$ & $1.0 \%$ & $4.0 \%$ \\
\hline $\begin{array}{c}\text { Responsibility and } \\
\text { Environmental Management }\end{array}$ & $5.8 \%$ & $53.8 \%$ & $11.8 \%$ & $8.3 \%$ & $3.6 \%$ & $1.6 \%$ & $2.0 \%$ & $1.6 \%$ & $5.4 \%$ & $6.1 \%$ \\
\hline Journal of Business Research & $10.6 \%$ & $27.8 \%$ & $36.1 \%$ & $10.5 \%$ & $0.7 \%$ & $1.0 \%$ & $0.4 \%$ & $6.0 \%$ & $1.7 \%$ & $5.1 \%$ \\
\hline Media and Communication & $18.4 \%$ & $3.8 \%$ & $4.6 \%$ & $12.9 \%$ & $26.3 \%$ & $6.9 \%$ & $4.2 \%$ & $13.9 \%$ & $7.9 \%$ & $1.4 \%$ \\
\hline
\end{tabular}

Note: The figures with bold are the top two topics for each journal.

The topic composition of the top two journals (Sustainability and the Journal of Cleaner Production) was relatively homogeneous by topic, suggesting that the two leading journals in the field of sustainability have reached some kind of maturity in both breadth and depth. However, the topic composition of the two journals varied somewhat, with Sustainability having a relatively high proportion of (T3) Sustainable consumer behavior and (T1) Education for sustainability, while the Journal of Cleaner Production had a relatively high proportion of (T7) Sustainable community and (T5) IT and finance for sustainability.

Most other journals were characterized by an asymmetrically high proportion of (T2) Sustainable communication. In particular, (T2) Sustainable communication accounted for more than half of the topic proportion of four journals including Developments in Corporate Governance and Responsibility. It is not surprising that about 30\% of the Journal of Sustainable Tourism was devoted to the topic of (T9) Sustainable tourism, as well as about $70 \%$ of Corporate Communications to (T2) Sustainable communication.

\section{Conclusions}

This study developed a topographic map of sustainability research and its interface with social media. By utilizing machine learning technology, we identified 10 latent topics, which provide a map that is different from that of the general sustainability research.

We also identified hot and cold topics by measuring the variation of topic distributions over time. From our research, we observed that the research's center of gravity has shifted 
from general discussion to specific applications, as shown by the rise of topics like (T3) Sustainable consumer behavior, (T7) Sustainable community, and (T9) Sustainable tourism, which were identified as being hot topics, while (T1) Education for sustainability was identified as the only cold topic. A topic's rise and fall may reflect the relative strength of social media's influence on each area.

Many of the top journals, based on the number of papers published in the relevant fields, showed a clear tendency for the topic distribution to be biased toward some topics, in particular, (T2) Sustainable communication. This suggests that the studies published in these journals mainly address the meaning of social media in terms of message communication.

Sustainability as a field of study requires interdisciplinarity, and in some respects it is more interdisciplinary than scientific research in general. Therefore, the task of grasping the topography and trends of the study has particularly important implications, which triggered a lot of related studies.

This study distinguishes itself from other studies in that it utilized an unstructured machine learning algorithm to reduce selection bias in identifying research topics. However, it must be noted that topic modeling does not automatically yield a valid outcome at the push of a button. The algorithms have rather a supporting role, and researchers need to make many decisions, which range from selecting appropriate algorithms to interpreting and labeling topics [26]. As a research method, topic modeling is, therefore, in the middle between a measurement-centric quantitative and an interpretation-centric form of qualitative method [26]. Nonetheless, this study offers conceptual frameworks to summarize the research in the field, and, in doing so, proposes opportunities for future inquiry.

One finding that emerged from an analysis of the literature on "sustainability + social media" is that most of the studies focused on how social media affects sustainability, i.e., how businesses leverage the power of social media to enhance their sustainability and competitiveness. But studies that analyze how a firm's social media strategy can benefit from its sustainable efforts were rare. Researchers need to note this gap, and, for hot or cold topics identified in the study, it is important that further work is done to establish a clearer understanding of why their popularity rises or falls.

Research linking the issue of sustainability with social media has soared over the past decade, however, it still represents only a tiny fraction of all sustainability research. Given the importance of the two megatrends in this era and the need for more effective drivers to implement sustainability, more robust research on the intersection of the two megatrends needs to be carried out in the future.

Author Contributions: J.H.L. developed the research framework, designed the model, analyzed the data, conducted the literature review, and wrote the original draft, supervised the draft; J.W. designed the research framework, conducted the literature review, wrote the original draft, designed the model and edited the manuscript; J.K. developed research design, collected and analyzed the data, wrote the original draft, supervised the research draft, and conducted the literature review. All authors have read and agreed to the published version of the manuscript.

Funding: This research received no external funding.

Institutional Review Board Statement: Not applicable.

Informed Consent Statement: Not applicable.

Data Availability Statement: Data available in a publicly accessible repository that does not issue DOIs. Publicly available datasets were analyzed in this study. This data can be found here: [www.scopus.com].

Conflicts of Interest: The authors declare no conflict of interest.

\section{References}

1. Eisenhardt, K.M.; Martin, J.A. Dynamic Capabilities: What Are They? Strateg. Manag. J. 2000, 21, 1105-1121. [CrossRef]

2. Smits, M.; Mogos, S. The Impact Of Social Media On Business Performance. In Proceedings of the European Conference on Information Systems, Utrecht, The Netherlands, 25-27 June 2013. 
3. Kietzmann, J.H.; Hermkens, K.; McCarthy, I.P.; Silvestre, B.S. Social Media? Get Serious! Understanding the Functional Building Blocks of Social Media. Bus. Horiz. 2011, 54, 241-251. [CrossRef]

4. Ramos-Rodríguez, A.-R.; Ruíz-Navarro, J. Changes in the Intellectual Structure of Strategic Management Research: A Bibliometric Study of the Strategic Management Journal, 1980-2000. Strateg. Manag. J. 2004, 25, 981-1004. [CrossRef]

5. Rosen, M. Sustainability: A Crucial Quest for Humanity-Welcome to a New Open Access Journal for a Growing Multidisciplinary Community. Sustainability 2009, 1, 1-4. [CrossRef]

6. Schoolman, E.D.; Guest, J.S.; Bush, K.F.; Bell, A.R. How Interdisciplinary Is Sustainability Research? Analyzing the Structure of an Emerging Scientific Field. Sustain. Sci. 2012, 7, 67-80. [CrossRef]

7. Olawumi, T.O.; Chan, D.W.M. A Scientometric Review of Global Research on Sustainability and Sustainable Development. J. Clean. Prod. 2018, 183, 231-250. [CrossRef]

8. White, M.A. Sustainability: I Know It When I See It. Ecol. Econ. 2013, 86, 213-217. [CrossRef]

9. Brown, B.J.; Hanson, M.E.; Liverman, D.M.; Merideth, R.W. Global Sustainability: Toward Definition. Environ. Manag. 1987, 11, 713-719. [CrossRef]

10. Modak, N.M.; Sinha, S.; Raj, A.; Panda, S.; Merigó, J.M.; Lopes de Sousa Jabbour, A.B. Corporate Social Responsibility and Supply Chain Management: Framing and Pushing Forward the Debate. J. Clean. Prod. 2020, 273, 122981. [CrossRef]

11. Schöggl, J.-P.; Stumpf, L.; Baumgartner, R.J. The Narrative of Sustainability and Circular Economy-A Longitudinal Review of Two Decades of Research. Resour. Conserv. Recycl. 2020, 163, 105073. [CrossRef]

12. Murphy, K. The Social Pillar of Sustainable Development: A Literature Review and Framework for Policy Analysis. Sustain. Sci. Pract. Policy 2012, 8, 15-29. [CrossRef]

13. Albino, V.; Berardi, U.; Dangelico, R.M. Smart Cities: Definitions, Dimensions, Performance, and Initiatives. J. Urban Technol. 2015, 22, 3-21. [CrossRef]

14. Seuring, S.; Müller, M. From a Literature Review to a Conceptual Framework for Sustainable Supply Chain Management. J. Clean. Prod. 2008, 16, 1699-1710. [CrossRef]

15. Winter, M.; Knemeyer, A.M. Exploring the Integration of Sustainability and Supply Chain Management: Current State and Opportunities for Future Inquiry. Int. J. Phys. Distrib. Logist. Manag. 2013, 43, 18-38. [CrossRef]

16. Fahimnia, B.; Sarkis, J.; Davarzani, H. Green Supply Chain Management: A Review and Bibliometric Analysis. Int. J. Prod. Econ. 2015, 162, 101-114. [CrossRef]

17. Engert, S.; Rauter, R.; Baumgartner, R.J. Exploring the Integration of Corporate Sustainability into Strategic Management: A Literature Review. J. Clean. Prod. 2016, 112, 2833-2850. [CrossRef]

18. de Medeiros, J.F.; Ribeiro, J.L.D.; Cortimiglia, M.N. Success Factors for Environmentally Sustainable Product Innovation: A Systematic Literature Review. J. Clean. Prod. 2014, 65, 76-86. [CrossRef]

19. Bui, T.D.; Ali, M.H.; Tsai, F.M.; Iranmanesh, M.; Tseng, M.-L.; Lim, M.K. Challenges and Trends in Sustainable Corporate Finance: A Bibliometric Systematic Review. J. Risk Financ. Manag. 2020, 13, 264. [CrossRef]

20. Lee, H.; Seo, H.; Geum, Y. Uncovering the Topic Landscape of Product-Service System Research: From Sustainability to Value Creation. Sustainability 2018, 10, 911. [CrossRef]

21. Sun, L.; Yin, Y. Discovering Themes and Trends in Transportation Research Using Topic Modeling. Transp. Res. Part C Emerg. Technol. 2017, 77, 49-66. [CrossRef]

22. Blei, D.M.; Ng, A.Y.; Jordan, M.I. Latent Dirichlet Allocation. J. Mach. Learn. Res. 2003, 3, 993-1022.

23. Griffiths, T.L.; Steyvers, M. Finding Scientific Topics. Proc. Natl. Acad. Sci. USA 2004, 101, 5228-5235. [CrossRef] [PubMed]

24. Gond, J.-P.; Crane, A. Corporate Social Performance Disoriented: Saving the Lost Paradigm? Bus. Soc. 2010, 49, 677-703. [CrossRef]

25. Strand, R.; Freeman, R.E.; Hockerts, K. Corporate Social Responsibility and Sustainability in Scandinavia: An Overview. J. Bus. Ethics 2015, 127, 1-15. [CrossRef]

26. Schmiedel, T.; Müller, O.; vom Brocke, J. Topic Modeling as a Strategy of Inquiry in Organizational Research: A Tutorial With an Application Example on Organizational Culture. Organ. Res. Methods 2019, 22, 941-968. [CrossRef]

27. Schubert, A.; Láng, I. The Literature Aftermath Of The Brundtland Report 'Our Common Future'. A Scientometric Study Based On Citations In Science And Social Science Journals. Environ. Dev. Sustain. 2005, 7, 1-8. [CrossRef]

28. Belz, F.-M.; Peattie, K. Sustainability Marketing: A Global Perspective, 2nd ed.; Wiley: Hoboken, NJ, USA, 2012; ISBN 978-1-11996619-7.

29. Turner, R.K. Sustainable Resource Conservation and Pollution Control: An Overview. In Sustainable Environmental Management: Principles and Practice; Turner, R.K., Ed.; Belhaven Press: London, England, 1988; pp. 1-25.

30. Pizzi, S.; Caputo, A.; Corvino, A.; Venturelli, A. Management Research and the UN Sustainable Development Goals (SDGs): A Bibliometric Investigation and Systematic Review. J. Clean. Prod. 2020, 276, 124033. [CrossRef]

31. Haan, G. de The BLK '21' Programme in Germany: A 'Gestaltungskompetenz'-based Model for Education for Sustainable Development. Environ. Educ. Res. 2006, 12, 19-32. [CrossRef]

32. Rieckmann, M. Future-Oriented Higher Education: Which Key Competencies Should Be Fostered through University Teaching and Learning? Futures 2012, 44, 127-135. [CrossRef]

33. From Agenda 21 to Target 4.7: The Development of Education for Sustainable Development-UNESCO Digital Library. Available online: https:// unesdoc.unesco.org/ark:/48223/pf0000261801 (accessed on 26 December 2020). 
34. Education for Sustainable Development. Available online: https://en.unesco.org/themes/education-sustainable-development (accessed on 26 December 2020).

35. Hasan, H.; Molla, A.; Cooper, V. Towards a Green IS Taxonomy. In Proceedings of the SIGGreen Workshop, Barcelona, Spain, 1-22 June 2012.

36. Prensky, M. Digital Natives, Digital Immigrants Part 1. Horizon 2001, 9, 1-6. [CrossRef]

37. Isacsson, A.; Gretzel, U. Facebook as an Edutainment Medium to Engage Students in Sustainability and Tourism. J. Hosp. Tour. Technol. 2011, 2, 81-90. [CrossRef]

38. Wang, S.; Wang, H. Social-Media-Based Knowledge Sharing: A Qualitative Analysis of Multiple Cases. Int. J. Knowl. Manag. (IJKM) 2018, 1, 19-29. [CrossRef]

39. Brønn, P.S.; Vrioni, A.B. Corporate Social Responsibility and Cause-Related Marketing: An Overview. Int. J. Advert. 2001, 20, 207-222. [CrossRef]

40. Dawkins, J.; Lewis, S. CSR in Stakeholde Expectations: And Their Implication for Company Strategy. J. Bus. Ethics 2003, 44, 185-193. [CrossRef]

41. Capriotti, P.; Moreno, Á. Corporate Citizenship and Public Relations: The Importance and Interactivity of Social Responsibility Issues on Corporate Websites. Public Relat. Rev. 2007, 33, 84-91. [CrossRef]

42. Fieseler, C.; Fleck, M.; Meckel, M. Corporate Social Responsibilityin the Blogosphere. J. Bus. Ethics 2010, 91, 599-614. [CrossRef]

43. Reisch, L.; Eberle, U.; Lorek, S. Sustainable Food Consumption: An Overview of Contemporary Issues and Policies. Sustain. Sci. Pract. Policy 2013, 9, 7-25. [CrossRef]

44. Kaplan, A.M.; Haenlein, M. Users of the World, Unite! The Challenges and Opportunities of Social Media. Bus. Horiz. 2010, 53, 59-68. [CrossRef]

45. Waddock, S.; Googins, B. The Paradoxes of Communicating Corporate Social Responsibility. In The Handbook of Communication and Corporate Social Responsibility; Wiley-Blackwell: Hoboken, NJ, USA, 2011; pp. 23-43. ISBN 978-1-4443-3634-4.

46. Cho, M.; Furey, L.D.; Mohr, T. Communicating corporate social responsibility on social media: Strategies, stakeholders, and public engagement on corporate Facebook. Bus. Prof. Commun. Q. 2017, 80, 52-69. [CrossRef]

47. Bowen, G.; Appiah, D.; Okafor, S. The Influence of Corporate Social Responsibility (CSR) and Social Media on the Strategy Formulation Process. Sustainability 2020, 12, 6057. [CrossRef]

48. Morsing, M. CSR Communication: What Is It? Why Is It Important? In Corporate Social Responsibility; Rasche, A., Morsing, M., Moon, J., Eds.; Cambridge University Press: Cambridge, UK, 2017; pp. 281-306. ISBN 978-1-107-11487-6.

49. White, K.; Habib, R.; Haddisty, D.J. How to SHIFT consumer behaviors to be more sustainable: A literature review and guiding framework. J. Mark. 2019, 83, 22-49. [CrossRef]

50. Mangold, W.G.; Faulds, D.J. Social Media: The New Hybrid Element of the Promotion Mix. Bus. Horiz. 2009, 52, 357-365. [CrossRef]

51. Pop, R.-A.; Săplăcan, Z.; Alt, M.-A. Social Media Goes Green-The Impact of Social Media on Green Cosmetics Purchase Motivation and Intention. Information 2020, 11, 447. [CrossRef]

52. Lee, K. Opportunities for Green Marketing: Young Consumers. Mark. Intell. Plan. 2008, 26, 573-586. [CrossRef]

53. Murwaningtyas, F.; Harisudin, M.; Irianto, H. Effect of Celebrity Endorser Through Social Media on Organic Cosmetic Purchasing Intention Mediated with Attitude. KnE Soc. Sci. 2020, 4, 152-165. [CrossRef]

54. Wood, J.; Khan, G.F. Social Business Adoption: An Empirical Analysis. Bus. Inf. Rev. 2016, 33, 28-39. [CrossRef]

55. Singh, S.; Sonnenburg, S. Brand Performances in Social Media. J. Interact. Mark. 2012, 26, 189-197. [CrossRef]

56. Heinonen, K. Consumer Activity in Social Media: Managerial Approaches to Consumers' Social Media Behavior. J. Consum. Behav. 2011, 10, 356-364. [CrossRef]

57. Li, Y.-M.; Lee, Y.-L.; Lien, N.-J. Online Social Advertising via Influential Endorsers. Int. J. Electron. Commer. 2012, 16, 119-154. [CrossRef]

58. Rauniar, R.; Rawski, G.; Yang, J.; Johnson, B. Technology Acceptance Model (TAM) and Social Media Usage: An Empirical Study on Facebook. J. Enterp. Inf. Manag. 2014, 27, 6-30. [CrossRef]

59. Chwialkowska, A. How Sustainability Influnencers Drive Green Lifestyle Adoption On Social Media: The Process Of Green Lifestyle Adoption Explained Through The Lenses of The Minority Influence Model and Social Learning Theory. Manag. Sustain. Dev. Sibiu Rom. 2019, 11, 33-42.

60. Ingenbleek, P.T.M.; Meulenberg, M.T.G.; Trijp, H.C.M.V. Buyer Social Responsibility: A General Concept and Its Implications for Marketing Management. J. Mark. Manag. 2015, 31, 1428-1448. [CrossRef]

61. Minton, E.; Lee, C.; Orth, U.; Kim, C.-H.; Kahle, L. Sustainable Marketing and Social Media. J. Advert. 2012, 41, 69-84. [CrossRef]

62. Chabowski, B.R.; Mena, J.A.; Gonzalez-Padron, T.L. The Structure of Sustainability Research in Marketing, 1958-2008: A Basis for Future Research Opportunities. J. Acad. Mark. Sci. 2011, 39, 55-70. [CrossRef]

63. Lučić, A. Measuring Sustainable Marketing Orientation-Scale Development Process. Sustainability 2020, 12, 1734. [CrossRef]

64. Brown, T.J.; Dacin, P.A. The Company and the Product: Corporate Associations and Consumer Product Responses. J. Mark. 1997, 61, 68-84. [CrossRef]

65. Luo, X.; Bhattacharya, C.B. Corporate Social Responsibility, Customer Satisfaction, and Market Value. J. Mark. 2006, 70, 1-18. [CrossRef] 
66. Olsen, M.C.; Slotegraaf, R.J.; Chandukala, S.R. Green Claims and Message Frames: How Green New Products Change Brand Attitude. J. Mark. 2014, 78, 119-137. [CrossRef]

67. IT and Sustainability: Bringing Best Practices to the Business. Available online: http://www.oracle.com/us/products/ applications/green/056899.pdf (accessed on 26 December 2020).

68. Martin, C.J.; Upham, P.; Budd, L. Commercial Orientation in Grassroots Social Innovation: Insights from the Sharing Economy. Ecol. Econ. 2015, 118, 240-251. [CrossRef]

69. Martin, C.J. The Sharing Economy: A Pathway to Sustainability or a Nightmarish Form of Neoliberal Capitalism? Ecol. Econ. 2016, 121, 149-159. [CrossRef]

70. Huang, L.; Zhao, Y.; Mei, L.; Wu, P.; Zhao, Z.; Mao, Y. Structural Holes in the Multi-Sided Market: A Market Allocation Structure Analysis of China's Car-Hailing Platform in the Context of Open Innovation. Sustainability 2019, 11, 5813. [CrossRef]

71. TRUFFER, B. User-Led Innovation Processes: The Development of Professional Car Sharing by Environmentally Concerned Citizens. Innov. Eur. J. Soc. Sci. Res. 2003, 16, 139-154. [CrossRef]

72. Ornetzeder, M.; Rohracher, H. Of Solar Collectors, Wind Power, and Car Sharing: Comparing and Understanding Successful Cases of Grassroots Innovations. Glob. Environ. Chang. 2013, 23, 856-867. [CrossRef]

73. Meelen, T.; Truffer, B.; Schwanen, T. Virtual User Communities Contributing to Upscaling Innovations in Transitions: The Case of Electric Vehicles. Environ. Innov. Soc. Transit. 2019, 31, 96-109. [CrossRef]

74. Shneor, R.; Zhao, L.; Flåten, B.-T. Advances in Crowdfunding: Research and Practice; Springer Nature: Berlin/Heidelberg, Germany, 2020.

75. Reilly, A.H.; Hynan, K.A. Corporate Communication, Sustainability, and Social Media: It's Not Easy (Really) Being Green. Bus. Horiz. 2014, 57, 747-758. [CrossRef]

76. Mercade Mele, P.; Molina Gomez, J.; Garay, L. To Green or Not to Green: The Influence of Green Marketing on Consumer Behaviour in the Hotel Industry. Sustainability 2019, 11, 4623. [CrossRef]

77. Norton, B.G. Sustainability: A Philosophy of Adaptive Ecosystem Management; University of Chicago Press: Chicago, IL, USA, 2005; ISBN 978-0-226-59521-4.

78. Daigle, C.; Vasseur, L. Is It Time to Shift Our Environmental Thinking? A Perspective on Barriers and Opportunities to Change. Sustainability 2019, 11, 5010. [CrossRef]

79. Verweij, P.; Cormont, A.; Hoetjes, P.; de Meyer, K.; van Bussel, T.; Roosenschoon, O.; Henkens, R.; Schmidt, A.; Janssen, S. CoDesigning a Data Platform to Impact Nature Policy and Management: Experiences from the Dutch Caribbean. Environ. Sci. Policy 2019, 100, 13-20. [CrossRef]

80. Riley, P.; Wang, R.; Wang, Y.; Feng, L. Global Warming: Chinese Narratives of the Future. Glob. Media China 2016, 1, 12-31. [CrossRef]

81. Ghazali, Z.; Zahid, M.; Kee, T.S.; Ibrahim, M.Y. A Step towards Sustainable Society: The Awareness of Carbon Dioxide Emissions, Climate Change and Carbon Capture in Malaysia. Int. J. Econ. Financ. Issues 2016, 6, 179-187.

82. Bain, J.; Chaban, N. An Emerging EU Strategic Narrative? Twitter Communication during the EU's Sustainable Energy Week. Comp. Eur. Polit. 2017, 15, 135-155. [CrossRef]

83. Gupta, A. Business and Globalisation the New Face of Micro Lending in India: A Case Study. Int. J. Bus. Glob. 2014, 12, 485-495. [CrossRef]

84. Roseland, M. Sustainable Community Development: Integrating Environmental, Economic, and Social Objectives. Prog. Plan. 2000, 54, 73-132. [CrossRef]

85. Wong, C.; Wood, J.; Paturi, S. Vertical Farming: An Assessment of Singapore City. Etropic Electron. J. Stud. Trop. 2020, 19, 228-248. [CrossRef]

86. Ciuccarelli, P.; Lupi, G.; Simeone, L. Visualizing the Data City: Social Media as A Source of Knowledge for Urban. Planning and Management; Springer Science \& Business Media: Berlin/Heidelberg, Germany, 2014; ISBN 978-3-319-02195-9.

87. Fang, L.; Huang, J.; Zhang, Z.; Nitivattananon, V. Data-Driven Framework for Delineating Urban Population Dynamic Patterns: Case Study on Xiamen Island, China. Sustain. Cities Soc. 2020, 62, 102365. [CrossRef]

88. Neilson, A.; Indratmo; Daniel, B.; Tjandra, S. Systematic Review of the Literature on Big Data in the Transportation Domain: Concepts and Applications. Big Data Res. 2019, 17, 35-44. [CrossRef]

89. Wang, Z.; Ke, L.; Cui, X.; Yin, Q.; Liao, L.; Gao, L.; Wang, Z. Monitoring Environmental Quality by Sniffing Social Media. Sustainability 2017, 9, 85. [CrossRef]

90. Kleinhans, R.; Van Ham, M.; Evans-Cowley, J. Using Social Media and Mobile Technologies to Foster Engagement and SelfOrganization in Participatory Urban Planning and Neighbourhood Governance. Plan. Pract. Res. 2015, 30, 237-247. [CrossRef]

91. Sullivan, J.; Xie, L. Environmental Activism, Social Networks and the Internet. China Q. 2009, 198, 422-432. [CrossRef]

92. Shim, K. Impact of Social Media on Power Relations of Korean Health Activism. Media Commun. 2014, 2, 72-83. [CrossRef]

93. Vu, H.T.; Blomberg, M.; Seo, H.; Liu, Y.; Shayesteh, F.; Do, H.V. Social Media and Environmental Activism: Framing Climate Change on Facebook by Global NGOs. Sci. Commun. 2020, 1075547020971644. [CrossRef]

94. Ganglbauer, E.; Reitberger, W.; Fitzpatrick, G. An Activist Lens for Sustainability: From Changing Individuals to Changing the Environment. In Persuasive Technology; Berkovsky, S., Freyne, J., Eds.; Springer: Berlin, Heidelberg, Germany, 2013 ; pp. 63-68.

95. Uldam, J. Social Media Visibility: Challenges to Activism. Media Cult. Soc. 2018, 40, 41-58. [CrossRef]

96. Liu, Z. Sustainable Tourism Development: A Critique. J. Sustain. Tour. 2003, 11, 459-475. [CrossRef] 
97. Sustainable Development I UNWTO. Available online: https://www.unwto.org/sustainable-development (accessed on 26 December 2020).

98. Williams, D.R. Sustainability and Public Access to Nature: Contesting the Right to Roam. J. Sustain. Tour. 2001, 9, 361-371. [CrossRef]

99. Mkono, M. Sustainability and Indigenous Tourism Insights from Social Media: Worldview Differences, Cultural Friction and Negotiation. J. Sustain. Tour. 2016, 24, 1315-1330. [CrossRef]

100. Contemporary Issues in Tourism Development, 1st ed; Butler, R.W.; Pearce, D.G. (Eds.) Routledge: Abingdon, UK, 2003.

101. Hawkins, R.; Middleton, V.T.C. Sustainable Tourism; Routledge: Abingdon, UK, 2016; ISBN 978-1-138-14650-1.

102. Khan, A.; Bibi, S.; Lorenzo, A.; Lyu, J.; Babar, Z.U. Tourism and Development in Developing Economies: A Policy Implication Perspective. Sustainability 2020, 12, 1618. [CrossRef]

103. Kim, J.; Wood, J. Service Sector Development in Asia: An Important Instrument of Growth. Asian-Pac. Econ. Lit. 2020, 34, 12-25. [CrossRef]

104. Cohen, E. The Impact of Tourism on the Physical Environment. Ann. Tour. Res. 1978, 5, 215-237. [CrossRef]

105. Sarkar, S.K.; George, B. Social Media Technologies in the Tourism Industry: An Analysis with Special Reference to Their Role in Sustainable Tourism Development. Int. J. Tour. Sci. 2018, 18, 269-278. [CrossRef]

106. Ayeh, J.K.; Leung, D.; Au, N.; Law, R. Perceptions and Strategies of Hospitality and Tourism Practitioners on Social Media: An Exploratory Study. In Information and Communication Technologies in Tourism 2012; Fuchs, M., Ricci, F., Cantoni, L., Eds.; Springer: Vienna, Austria, 2012; pp. 1-12.

107. Hays, S.; Page, S.J.; Buhalis, D. Social Media as a Destination Marketing Tool: Its Use by National Tourism Organisations. Curr. Issues Tour. 2013, 16, 211-239. [CrossRef]

108. Bosangit, C.; McCabe, S.; Hibbert, S. What Is Told in Travel Blogs? Exploring Travel Blogs for Consumer Narrative Analysis. In Information and Communication Technologies in Tourism 2009; Höpken, W., Gretzel, U., Law, R., Eds.; Springer: Vienna, Austria, 2009; pp. 61-71.

109. Lee, H.A.; Law, R.; Murphy, J. Helpful Reviewers in TripAdvisor, an Online Travel Community. J. Travel Tour. Mark. 2011, 28, 675-688. [CrossRef]

110. O'Connor, P. User-Generated Content and Travel: A Case Study on Tripadvisor.Com. In Information and Communication Technologies in Tourism 2008; O'Connor, P., Höpken, W., Gretzel, U., Eds.; Springer: Vienna, Austria, 2008; pp. 47-58, ISBN 978-3-211-77279-9.

111. Broek-Serlé, F.N.V. Green Supply Chain Management, Marketing Tool or Revolution; NHTV Breda University of Applied Sciences: Breda, The Netherlands, 2010.

112. Fadeeva, Z. Promise of Sustainability Collaboration-Potential Fulfilled? J. Clean. Prod. 2005, 13, 165-174. [CrossRef]

113. Henriques, I.; Sadorsky, P. The Relationship Between Environmental Commitment and Managerial Perceptions of Stakeholder Importance. Acad. Manage. J. 1999, 42, 87-99. [CrossRef]

114. Tseng, M.-L.; Lim, M.K.; Wu, K.-J.; Peng, W.-W. Improving Sustainable Supply Chain Capabilities Using Social Media in a Decision-Making Model. J. Clean. Prod. 2019, 227, 700-711. [CrossRef]

115. Sigala, M. Customer Involvement in Sustainable Supply Chain Management: A Research Framework and Implications in Tourism. Cornell Hosp. Q. 2014, 55, 76-88. [CrossRef]

116. Zoeteman, B.C.J. What Is behind the Leadership Shift in Sustainable Development from Politicians to CEOs? Environ. Dev. 2013, 8, 113-130. [CrossRef]

117. Abbas, J.; Aman, J.; Nurunnabi, M.; Bano, S. The Impact of Social Media on Learning Behavior for Sustainable Education: Evidence of Students from Selected Universities in Pakistan. Sustainability 2019, 11, 1683. [CrossRef] 